\title{
CHEMICAL COMPOSITIONS OF SUPERNATES STORED IN SRP HIGH LEVEL WASTE TANKS
}

\author{
R. S. ONDREJCIN
}

$$
11
$$

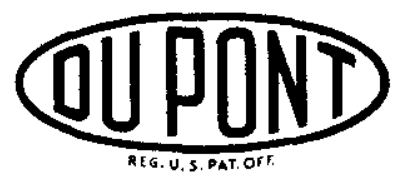

E. I. du Pont de Nemours \& Co. Savannah River Laboratory

Aiken, S. C. 29801

PREPARED FOR THE U. S. ATOMIC ENERGY COMMISSION UNDER CONTRACT AT(07.2)-1 
This report was prepared as an account of work sponsored by the United States Government. Neither the United States nor the United States Atomic Energy Commission, nor any of their employees, nor any of their contractors, subcontractors, or their employees, makes any warranty, express or implied, or assumes any legal liability or responsibility for the accuracy, completeness or usefulness of any information, apparatus, product or process disclosed, or represents that its use would not infringe privately owned rights.

Printed in the United States of America

$$
\text { Available from }
$$

National Technical Information Service

U. S. Department of Commerce

5285 Port Royal Road

Springfield, Virginia 22151

Price: Printed Copy $\$ 4.00$; Microfiche $\$ 1.45$ 


\section{INTERNAL DISTRIBUTION}

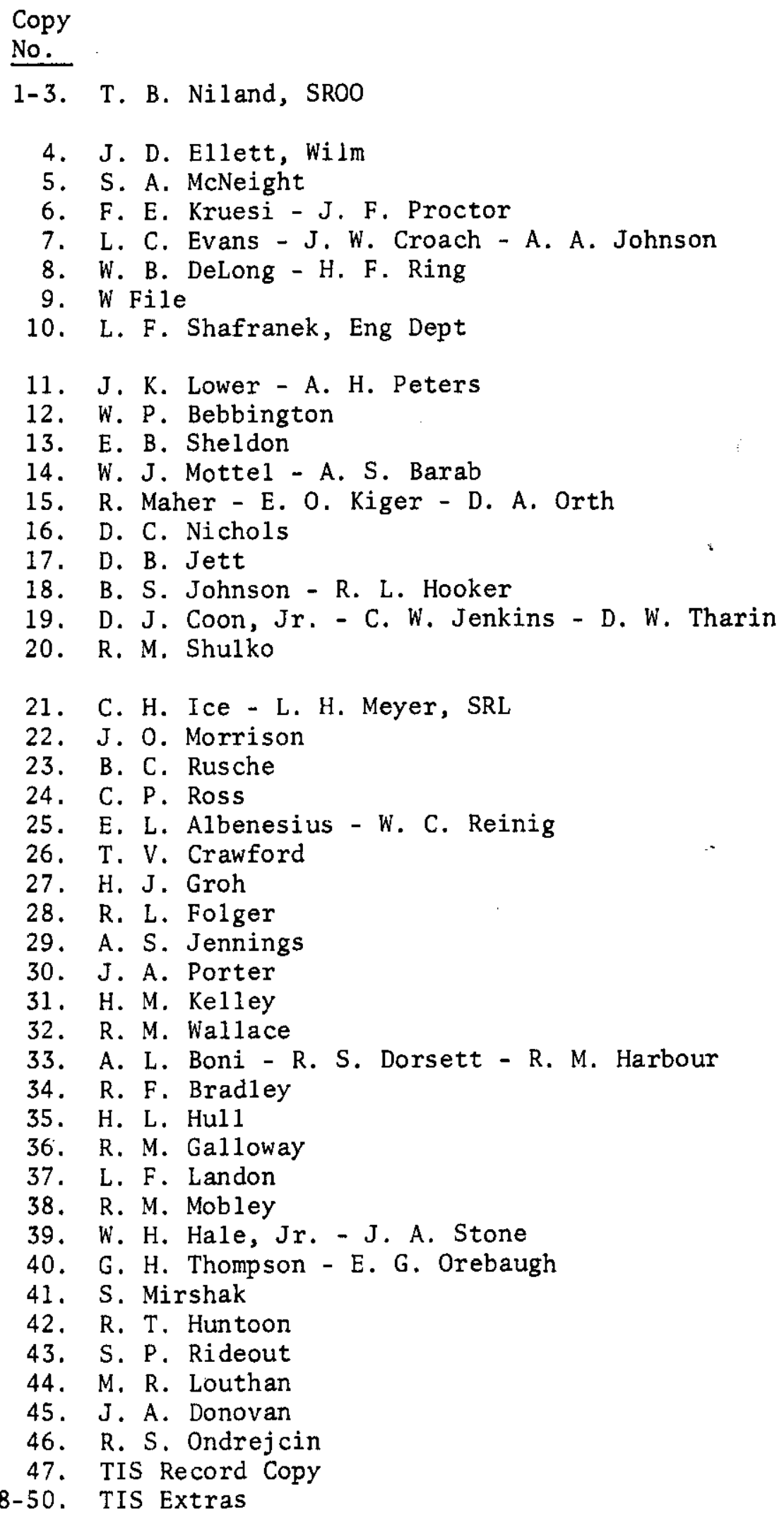




\section{CHEMICAL COMPOSITIONS OF SUPERNATES} STORED IN SRP HIGH LEVEL WASTE TANKS

by

R. S. Ondrejcin

$$
\text { Approved by }
$$

R. T. Huntoon, Research Manager Nuclear Materials Division

Publication Date: August 1974
E. I. du Pont de Nemours \& Co. Savannah River Laboratory Aiken, S. C. 29801

PREPARED FOR THE U. S. ATOMIC ENERGY COMMISSION UNDER CONTRACT AT107-21-1 


\begin{abstract}
High-1evel radioactive wastes from the Savannah River Plant separations processes are stored in large, underground, carbon steel tanks. Wastes accumulate in three forms: supernate, sludge, and salt cake. As carbon steel is susceptible to stress-corrosion cracking (SCC) and cracks have been observed in several of the tanks, studies are in progress to determine the effects of supernate on SCC of tank materials.

The results of chemical analyses of separations process waste supernates from sixteen waste storage tanks (seven in F-Area and nine in H-Area) are reported. Waste compositions must be known to evaluate corrosion phenomena that may limit the life of storage tanks. For example, the analyses provide a basis for preparing synthetic, nonradioactive wastes for corrosion studies simulating actual tank and cooling soil exposures. The average $\left[\mathrm{NO}_{3}^{-}\right] /\left[\mathrm{NO}_{2}^{-}\right]$ ratio of supernates from 16 tanks was 1 in F-Area and 3 in H-Area. The high ratio in H-Area could increase the tendency for these wastes to cause stress corrosion cracking. Other nonradioactive constituents analyzed in the supernates were $\mathrm{Na}, \mathrm{Al}(\mathrm{OH})_{4}^{-}, \mathrm{OH}^{-}$, $\mathrm{CO}_{3}^{-2}, \mathrm{SO}_{4}^{-2}, \mathrm{PO}_{4}^{-3}, \mathrm{Cl}^{-}, \mathrm{CrO}_{4}^{-2}, \mathrm{~F}^{-}, \mathrm{Fe}, \mathrm{Hg}, \mathrm{NH}_{4}^{+}, \mathrm{Ag}, \mathrm{Pb}$, and $\mathrm{U}$.

Analyses were also performed for seventeen radioactive species: $134,137 \mathrm{Cs}$, at about $10^{10} \mathrm{~d} /(\mathrm{min})(\mathrm{m} 1)$, contributed about $99 \%$ of the gamma activity; ${ }^{10}{ }^{3}, 106 \mathrm{Ru}$ contributed about $10^{7} \mathrm{~d} /$ (min) (ml). ${ }^{89,90} \mathrm{Sr}$, both biologically important beta emitters, were quite low, as expected, at about $10^{5} \mathrm{~d} /(\mathrm{min})(\mathrm{ml})$. Plutonium alpha was practically absent at $10^{3}-10^{4} \mathrm{~d} /(\mathrm{min})(\mathrm{ml})$. The reducing normality and density were also measured.

The electrochemical behavior of the mild steel used to construct the waste tanks was similar in either actual waste supernates or synthetic solutions. This similarity indicates that the results of laboratory corrosion tests should be directly applicable to the actual waste tanks.
\end{abstract}




$$
\text { ... }
$$




\section{CHEMICAL COMPOSITIONS OF SUPERNATES STORED IN SRP HIGH LEVEL WASTE TANKS}

\section{INTRODUCTION}

High-level radioactive wastes from the Savannah River P1ant (SRP) separations processes are stored in large, underground carbon steel tanks. Decay heat due to the radioactivity of the wastes is removed by corrosion-inhibited water pumped through carbon steel cooling coils. The primary steel containers are contained within secondary steel pans; these secondary containers are in turn supported by a concrete outer she11. A 2.5-ft-wide annulus separates the primary and secondary containers. ${ }^{1}$

Most of the high-level wastes at SRP are byproducts of the Purex (principal process in F-Area) and enriched uranium (principal process in H-Area) processes. The Purex process recovers plutonium and uranium from irradiated natural uranium, and the enriched uranium process recovers plutoniom and enriched uranium from uranium-aluminum fuel. Other recovery processes have also been used from time-to-time in both areas for the separation of other isotopes. ${ }^{3}$ Each recovery process produces a characteristic waste; however, mixing with other wastes, radiation-induced changes in composition, evaporation, precipitation of insoluble constituents (sludge), and subsequent removal of sludge make development of a meaningful generalization of waste compositions based on flowsheet or process analysis impossible.

The high-leve1 wastes generated by the separations processes are transferred into the tanks for aging to reduce the residual radioactivity through decay of short-lived radioisotopes. Wastes are present in these tanks in three forms: supernate (an aqueous solution), sludge (a gel containing the insoluble components of the wastes that settle to the tank bottom with some trapped supernate), and salt cake (salt crystals formed by evaporation of water from the supernate).

The carbon steel in the tanks is susceptible to stress corrosion cracking in nitrate and caustic solutions, and stress corrosion cracks have been observed in three tanks. Subsequent laboratory investigations ${ }^{1,4}$ confirmed the probability of stress corrosion cracking and indicated that stress-relief annealing of as-welded tanks should minimize the cracking susceptibility. The six tanks fabricated after these laboratory investigations have been stress-relieved for that reason. Additional studies are currently in progress to assess the susceptibility, if any, of stress-relieved carbon steel to stress corrosion cracking at stress levels approaching the expected stresses in filled tanks. 
The aggressiveness of corrosion attack on any material clearly depends on the chemical composition of the corrodent as well as other variables, such as, temperature, liquid-vapor interface conditions, and stress level. Although chemical analyses of high-level wastes have been made over a period of years, 2 a detailed study of tank-to-tank variations had not been performed, and new methods, which provide more accurate analyses, have been developed since the earlier analyses.

These factors indicated the need for accurate determinations of the actual waste compositions so that corrosion testing could be performed in solutions known to be representative of the stored wastes.

\section{SUMMARY}

The ranges of concentrations of the major nonradioactive components in the supernates found in the sixteen tanks that were sampled (seven in F-Area and nine in H-Area) are:

\section{TABLE I: CONCENTRATION RANGE OF MAJOR CONSTITUENTS}

\begin{tabular}{llll} 
& \multicolumn{2}{c}{ Molarity } & Ranges \\
$\mathrm{Na}^{+}$ & F-Area & & H-Area \\
$\mathrm{NO}_{3}^{-}$ & & $1.0-12.5$ & $5.7-12.5$ \\
$\mathrm{NO}_{2}^{-}$ & & $0.5-3.1$ & $0.2-3.2$ \\
$\mathrm{Al}(\mathrm{OH})_{4}^{-}$ & $0.4-0.8$ & $0.4-1.6$ \\
$\mathrm{OH}^{-}$ & $1.1-6.3$ & $0.8-3.8$
\end{tabular}.

The average $\left[\mathrm{NO}_{3}^{-}\right] /\left[\mathrm{NO}_{2}^{-}\right]$ratio was 1 in $\mathrm{F}$-Area and 3 in $\mathrm{H}$-Area. The high ratio in H-Area could increase the tendency for these wastes to cause stress corrosicn cracking. Other nonradioactive constituents analyzed in the supernates were $\mathrm{CO}_{3}^{-2}, \mathrm{SO}_{4}^{-2}, \mathrm{PO}_{4}^{-3}, \mathrm{Cl}^{-}, \mathrm{CrO}_{4}^{-2}, \mathrm{~F}^{-}, \mathrm{Fe}, \mathrm{Hg}, \mathrm{NH}_{4}^{+}, \mathrm{Ag}, \mathrm{Pb}$, and $\mathrm{U}$.

Analyses were also performed for seventeen radioactive species: $134,137 \mathrm{Cs}$, at about $10^{10} \mathrm{~d} /(\mathrm{min})(\mathrm{ml})$, contributed about $99 \%$ of the gamma activity; $103,106 \mathrm{Ru}$, contributed about $10^{7} \mathrm{~d} /$ (min) (m1). ${ }^{89,90} \mathrm{Sr}$, both biologically important beta emitters, were quite low, as expected, at about $10^{5} \mathrm{~d} /(\mathrm{min})(\mathrm{ml})$. Plutonium alpha was practically absent at $10^{3}-10^{4} \mathrm{~d} /(\mathrm{min})(\mathrm{ml})$. The reducing normality and density were also measured. 
The electrochemical behavior of the mild steel used to construct the waste tanks was similar in either actual waste supernates or synthetic solutions. This similarity indicates that the results of laboratory corrosion tests should be directly applicable to the actual waste tanks.

\section{SAMPLING AND ANALYSIS TECHNIQUES}

Samples were obtained from selected tanks by pumping waste supernate into a sampling loop. The intake from the pump was 1 to 2 feet below the liquid surface. Samples were taken after supernate had been pumped through the loop for several minutes. The $250 \mathrm{ml}$ samples of waste supernates were taken from Tanks 1, $2,4,5,6,8$, and 18 in F-Area and Tanks 9 through 15, 21, and 24 in H-Area. Shielded transfer containers called "doorstops" were used to transfer the samples from the waste tanks to the Savannah River Laboratory (SRL) for analyses. The analytical technique used depended on the ion, isotope, or material property of interest. The techniques used for each analysis are given in Appendix A.

\section{WASTE COMPOSITIONS}

The ranges of concentrations of the major constituents found in the waste supernates are shown in Table I. The H-Area and F-Area analyses are listed separately because of the different separations processes used. The composition ranges overlap: in F-Area the average $\left[\mathrm{NO}_{3}^{-}\right] /\left[\mathrm{NO}_{2}^{-}\right]$ratio is about 1 (over a range of 0.7 to 3.4 ) while in H-Area this average is about 3 (range 0.6 to 3.2 ). The significance of this variation is discussed below. Also, the $\mathrm{Al}(\mathrm{OH})_{\overline{4}}^{-}$concentration in $\mathrm{H}-\mathrm{Area}$ wastes was typically higher than in F-Area wastes, because in the enriched uranium process both cladding and core of aluminum-uranium fuel tubes are dissolved, and aluminum is added to enhance the extraction of uranium. The tank-to-tank variations in concentration of each analyzed component are summarized in Appendix B; radioisotopic analyses, reducing normalities, and densities for the waste supernates from each tank are also presented in Appendix B.

The sodium, hydroxide, and nitrate ions in the supernate are primarily from the sodium hydroxide added to neutralize both the Purex and enriched uranium process wastes, and from nitric acid not removed in the acid recovery operation. Although nitrite was occasionally added to the wastes in the past during nitric acid recovery, the nitrite is unstable in acid solutions and is oxidized to nitrate. The nitrite found in the wastes is produced (after neutralization) by radiolysis during waste storage. The $\mathrm{Al}(\mathrm{OH}) \overline{4}$ 
is present in the F-Area wastes because of incomplete removal of aluminum during dejacketing or inadequate rinsing of the dejacketed slugs. The $\mathrm{Al}(\mathrm{OH})_{4}$ in the $\mathrm{H}$-Area wastes is from the aluminum in the reactor fuel tubes and from the aluminum additions to the process. The concentrations of sodium, nitrate, nitrite, hydroxy1, and $\mathrm{Al}(\mathrm{OH})_{4}$ ions increase as the wastes are evaporated until saturation is reached; sodium nitrate and sodium nitrite then precipitate as the major components of the salt cake. The evaporation-precipitation process leads to higher and higher hydroxyl ion and $\mathrm{A} 1(\mathrm{OH})_{\overline{4}}$ concentrations.

The minor components of the waste supernates come from a variety of sources. The ranges of concentrations of these components are shown in Table II.

TABLE II. CONCENTRATION RANGE OF MINOR CONSTITUENTS

\begin{tabular}{|c|c|c|}
\hline \multirow[b]{2}{*}{ Constituent } & \multicolumn{2}{|c|}{ Ranges } \\
\hline & F-Area & H-Area \\
\hline $\mathrm{CO}_{3}^{-2}$ & $<0.1-0.3 \mathrm{M}$ & $<0.1-0.3 \mathrm{M}$ \\
\hline $\mathrm{SO}_{4}^{-2}$ & $0.02-0.18 \mathrm{M}$ & $0.02-0.08 \mathrm{M}$ \\
\hline $\mathrm{PO}_{4}^{-3}$ & $0.02-0.08 \mathrm{M}$ & $<0.01-0.05 \mathrm{M}$ \\
\hline $\mathrm{C}^{-}$ & $0.03-0.11 \mathrm{M}$ & $0.005-0.029 \mathrm{M}$ \\
\hline $\mathrm{CrO}_{4}^{-2}$ & $0.004-0.009 \mathrm{M}$ & $0.001-0.005 \mathrm{M}$ \\
\hline $\mathrm{F}^{-}$ & $0.002-0.004 \mathrm{M}$ & $0.001-0.004 \mathrm{M}$ \\
\hline $\mathrm{Fe}$ & $7-50 \times 10^{-5} \mathrm{M}$ & $0.2-6 \times 10^{-5} \mathrm{M}$ \\
\hline $\mathrm{Hg}$ & $<20-320 \mathrm{\mu g} / \mathrm{ml}$ & $60-340 \mu \mathrm{g} / \mathrm{m} 1$ \\
\hline $\mathrm{NH}_{4}^{+}$ & $7-8 \mu \mathrm{g} / \mathrm{m} 1$ & $<1-67 \mu \mathrm{g} / \mathrm{m} 1$ \\
\hline $\mathrm{Ag}$ & $<0.04-3 \mu \mathrm{g} / \mathrm{ml}$ & $0.1-4 \mu \mathrm{g} / \mathrm{mI}$ \\
\hline $\mathrm{Pb}$ & $<0.02 \mu \mathrm{g} / \mathrm{m} 1$ & $2-58 \mu \mathrm{g} / \mathrm{ml}$ \\
\hline $\mathrm{U}$ & $4-16 \mu \mathrm{g} / \mathrm{m} 1$ & $0.4-6 \mu \mathrm{g} / \mathrm{m} 1$ \\
\hline Reducing Normality & $0.005-0.28 \mathrm{~N}$ & $<0.01-0.3 \mathrm{~N}$ \\
\hline Density & $1.20-1.41 \mathrm{~g} / \mathrm{m} 1$ & $1.20-1.41 \mathrm{~g} / \mathrm{m} 1$ \\
\hline
\end{tabular}

The carbonate ion $\left(\mathrm{CO}_{3}^{-2}\right)$ in both $\mathrm{F}$ - and $\mathrm{H}$-Areas may result from radiation-induced degradation of organic materials introduced in the extraction process, or from carbon dioxide absorbed from air circulated over the waste supernate to prevent buildup 
of radiolytically produced hydrogen. The phosphate $\left(\mathrm{PO}_{4}^{-3}\right)$ ions result from degradation of organic materials, chiefly tributyl phosphate (TBP). Additionally, such degradation controls the value of the reducing normality. Thus, the reducing normality and the concentration of $\mathrm{CO}_{3}^{-2}$ and $\mathrm{PO}_{4}^{-3}$ clearly depend on the age of the waste, as well as the particular process producing the waste.

The majority of the sulfate ions $\left(\mathrm{SO}_{4}^{-2}\right)$ in the supernates from both $\mathrm{F}$ - and H-Areas comes from the ferrous sulfamate used for plutonium and neptunium valence adjustment in the Purex and enriched uranium processes. The chromate ion $\left(\mathrm{CrO}_{4}^{-2}\right)$ is a corrosion product resulting from either corrosion of stainless steel components in the process and waste handling systems, or from the occasional electrolytic dissolution of stainless-steel-clad fuel. Such dissolution and corrosion can also account for the presence of Fe ions. Chloride ion is probably an impurity in the sodium hydroxide added to neutralize acidic wastes, and may also result from special separation processes such as the Tramex Process for recovery of Am and $\mathrm{Cm}$. Both fluorides and mercury are used as catalysts for fuel and target dissolution. Traces of ammonium ion $\left(\mathrm{NH}_{4}^{+}\right)$probably come from the reduction of $\mathrm{NO}_{3}^{-}$in the dissolution process. Silver is used in the dissolver stack scrubbers for removal of radioactive iodine isotopes, and uranium enters the waste streams because of small losses in the separations processes. The source of lead in the supernates is uncertain.

The supernates were also analyzed for radioactivity. The constituents of principal biological interest were cesium, strontium, and plutonium. The ranges of radioactive component concentrations are shown in Table III. The major source of gamma activity (>99\%) in the supernates were the isotopes of ce-

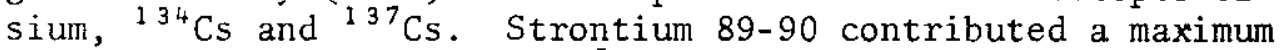
beta activity of only $3 \times 10^{5} \mathrm{~d} /(\mathrm{min})(\mathrm{m} 1)$ in Tank 9 of H-Area; the majority of the strontium would be expected in the sludge. Plutonium contributed about $10^{3}$ to $10^{5} \mathrm{~d} /(\mathrm{min})(\mathrm{m} 1)$ of alpha activity in the waste supernates and would also be expected largely as a precipitate in the sludge.

\section{CORROSION IN WASTE SOLUTIONS}

Mild steel is known to be susceptible to stress corrosion cracking in both nitrate and hydroxide solutions. ${ }^{6}$ Cracking in both solutions is intercrystalline, and the two forms of cracking are similar with regard to the effects of stress, cold work, and probably the nature of corrosion. Nitrate and caustic (hydroxide) cracking generally occur in mild steels within a specific range of carbon contents: from $0.02 \mathrm{wt} \%$ to $0.25 \mathrm{wt} \%$. Although most investigations have been made in relatively simple, 
TABLE III. CONCENTRATION RANGE OF RADIOACTIVE CONSTITUENTS

\begin{tabular}{|c|c|c|c|c|}
\hline \multirow[b]{3}{*}{ Constituent } & \multicolumn{4}{|c|}{ Concentration, $\mathrm{d} /(\min )(\mathrm{m} 1)$} \\
\hline & \multicolumn{2}{|c|}{ F-Area } & \multicolumn{2}{|c|}{ H-Area } \\
\hline & Lowest & Highest & Lowest & Highest \\
\hline $2{ }^{43} \mathrm{Am}$ & $<2 \times 10^{4}$ & $12 \times 10^{4}$ & $<0.1 \times 10^{4}$ & $0.2 \times 10^{4}$ \\
\hline${ }^{141} \mathrm{Ce}$ & & ND & $<1 \times 10^{3}$ & $<26 \times 10^{3}$ \\
\hline${ }^{144} \mathrm{Ce}$ & ND & $<15 \times 10^{4}$ & $<0.5 \times 10^{4}$ & $<26 \times 10^{4}$ \\
\hline${ }^{60} \mathrm{Co}$ & - & - & $<2 \times 10^{3}$ & $7 \times 10^{3}$ \\
\hline${ }^{134} \mathrm{Cs}$ & $1 \times 10^{8}$ & $27 \times 10^{8}$ & $0.9 \times 10^{8}$ & $10 \times 10^{8}$ \\
\hline${ }^{137} \mathrm{Cs}$ & $4 \times 10^{9}$ & $26 \times 10^{9}$ & $1 \times 10^{9}$ & $8 \times 10^{9}$ \\
\hline${ }^{154} \mathrm{Eu}$ & ND & $1 \times 10^{4}$ & $<0.2 \times 10^{4}$ & $0.3 \times 10^{4}$ \\
\hline${ }^{95} \mathrm{Nb}$ & ND & $98 \times 10^{3}$ & $<0.9 \times 10^{3}$ & $1 \times 10^{3}$ \\
\hline${ }^{103} \mathrm{Ru}$ & ND & $10.8 \times 10^{7}$ & $<0.01 \times 10^{7}$ & $0.29 \times 10^{7}$ \\
\hline${ }^{106} \mathrm{Ru}$ & $3 \times 10^{7}$ & $67 \times 10^{7}$ & $0.09 \times 10^{7}$ & $0.4 \times 10^{7}$ \\
\hline${ }^{89} \mathrm{Sr}$ & $<0.2 \times 10^{4}$ & $<1 \times 10^{4}$ & $<0.02 \times 10^{4}$ & $<2 \times 10^{4}$ \\
\hline${ }^{90} \mathrm{Sr}$ & $1 \times 10^{5}$ & $12 \times 10^{5}$ & $0.2 \times 10^{5}$ & $21 \times 10^{5}$ \\
\hline${ }^{95} \mathrm{Zr}$ & ND & $35 \times 10^{4}$ & $0.3 \times 10^{4}$ & $<0.6 \times 10^{4}$ \\
\hline Gross alpha & $<0.5 \times 10^{4}$ & $1 \times 10^{4}$ & $0.5 \times 10^{4}$ & $40 \times 10^{4}$ \\
\hline Total Pu & $<0.01 \times 10^{4}$ & $0.5 \times 10^{4}$ & $0.001 \times 10^{4}$ & $14 \times 10^{4}$ \\
\hline
\end{tabular}

\begin{tabular}{llllll} 
& \multicolumn{4}{c}{ Concentration, $\mathrm{c} /(\mathrm{min})(\mathrm{m} 1)$} \\
\cline { 2 - 3 } Constituent & \multicolumn{2}{c}{ F-Area } & & \multicolumn{2}{c}{ H-Area } \\
\cline { 3 - 4 } Gowest & Highest & & Lowest & Highest \\
Gross beta & $3 \times 10^{7}$ & $7 \times 10^{7}$ & & $2 \times 10^{7}$ & $4 \times 10^{7}$ \\
Gross gamma & $8 \times 10^{7}$ & $24 \times 10^{7}$ & & $2 \times 10^{7}$ & $8 \times 10^{7}$
\end{tabular}

- Not requested.

ND Not detected in gamma scan after cesium removal; see Appendix A. 
single-component solutions, sodium hydroxide additions to a sodium nitrate solution prevented nitrate cracking, ${ }^{7}$ and there are indications that sodium nitrate additions to caustic solutions inhibit caustic cracking. ${ }^{8}$ Other investigations showed that small additions of the chloride ion in $\mathrm{NaNO}_{3}$ solutions inhibited stress corrosion, but that when the chloride ion was added in combination with the $\mathrm{NH}_{4}^{+}$ion, inhibition was much less. ${ }^{9}$ Additionally, some investigators have shown that the nitrite ion is an effective stress corrosion inhibitor in sodium nitrate solutions, while other investigations have indicated that nitrite additions to sodium nitrate solutions accelerate cracking of mild steels. ${ }^{10}$

Development of an understanding of possible inhibition and accelerating effects of minor constituents in the complex separation process waste will be difficult, particularly in view of apparent conflicts in the literature. Oxygen is claimed by one group of investigators ${ }^{11}$ to be of great importance in assisting cracking in nitrate solutions; other investigators claim that oxygen has no effect, ${ }^{12}$ and studies in hydroxide solutions indicate that bubbling oxygen through a boiling solution stops cracking. ${ }^{8}$ Additionally, caustic cracking is often controlled in many industrial applications by maintaining a $\mathrm{Na}_{2} \mathrm{SO}_{4}: \mathrm{NaOH}$ ratio $>2.5$, even though a statistical evaluation of the practice shows no beneficial effect, ${ }^{13}$ and sulfate additions to nitrate solutions have been observed to accelerate cracking. Phosphate and carbonate additions may be effective in retarding both caustic and nitrate cracking; however, their effectiveness probably depends on the nitrate-to-caustic ratio, $\mathrm{pH}$, and the overall composition of the solution. Parkins ${ }^{14}$ has stated that "the potency (with respect to stress cracking) of a nitrate-based solution depends upon its $\mathrm{pH}$, and the presence or otherwise of oxidizing additions on substances capable of forming insoluble iron salts..... (however) since particular cations may exert an effect, these generalized statements ... are subject to systematic and detailed study of the whole question of waste composition."

The corrosion literature supports the necessity of a detailed study to determine the susceptibility of mild steel to cracking in any specific composition. As stated in a recent review article, 14 "although knowledge of the problem has increased, it remains the case that understanding of the environmental aspects of the phenomenon in particular is still so poor that it is frequently impossible to decide with confidence and without recourse to experiment, whether or not untried environments will promote such failure." In view of this situation, it is difficult, if not impossible, to select a typical, a most aggressive, or a least aggressive waste solely from the chemical composition. The necessity of conducting corrosion experiments in solutions closely matched to the chemical composition of the wastes becomes apparent. 


\section{SYNTHETIC WASTES}

Potentiostatic polarization measurements for mild steel immersed in actual waste supernates from $\mathrm{F}$ - and $\mathrm{H}$-Areas were compared with similar measurements for synthetic supernates to ensure that laboratory corrosion studies can predict accurately the electrochemical behavior of the waste tanks. The compositions of the actual and synthetic wastes used in this study are summarized in Table IV. The potentiostatic polarization curves for mild steel in the synthetic waste solutions were quite similar to those in the actual waste supernates (Figures 1 and 2). These figures indicate the electrochemical behavior of mild steel in the synthetic solutions is nearly identical to the behavior in actual waste supernates. Therefore, corrosion studies in synthetic solutions mixed to match the chemical composition of a specific plant waste will likely provide data directly applicable to the behavior of mild steel in that waste. The more-anodic open circuit potential $(-0.1 \mathrm{~V}$ vs. $-0.5 \mathrm{~V}$. at a current density of 0$)$ and the high critical current densities for $\mathrm{H}$-Area wastes in Figures 1 and 2 were shown to be due to the presence of mercury in solution, probably as $\mathrm{HHgO}_{2}^{-}$, at a concentration of $2 \times 10^{-5} \mathrm{M}$ or greater.

\section{CONCLUSIONS}

These studies have shown that the compositions of the highlevel wastes stored in both $\mathrm{F}$ - and H-Areas are quite variable, and the composition ranges for the two areas overlap for all major and practically all minor nonradioactive constituents. Based on the average compositions of the major constituents, the nitrate-to-nitrite ratio is 1 in F-Area and 3 in $\mathrm{H}$-Area. Therefore, the inhibiting effect of nitrite on carbon steel pitting, which can be the precursor of cracking, "would be expected to be generally greater in F-Area tanks than in $\mathrm{H}-$ Area tanks.

Additiona11y, the following points were established:

1. Nonradioactive synthetics prepared according to the analyses in this report react with waste tank steel similarly to the way actual wastes do.

2. Mercury, primarily present in the H-Area sludge, is also slightly soluble in basic solution. This component increases the average waste tank potential by about $0.4 \mathrm{~V}$ anodically and causes a high critical current density in potentiostatic polarization curves. A potential or current density that is too high can cause corrosion effects leading to the degradation of mechanical properties of metals. 
TABLE IV. COMPOSITION OF SYNTHETIC AND

ACTUAL SUPERNATANT WASTE SOLUTIONS

Concentration, M

\begin{tabular}{|c|c|c|c|c|}
\hline Synt & tic & Waste & Solution & from Tank No. \\
\hline F-Area & H-Area & 4 & 11 & 12 \\
\hline
\end{tabular}

$\mathrm{NO}_{3}^{-}$

2.4

3.4

2.4

3.5

3.3

$\mathrm{NO}_{2}^{-}$

3.1

1.2

3.1

0.8

1.5

$\mathrm{Al}_{2}^{-}$

0.5

0.5

0.54

0.6

0.4

$\mathrm{OH}^{-}$

1.4

0.9

2.8

0.79

1.0

$\mathrm{CO}_{3}^{2-}$

0.18

0.10

0.18

0.10

0.15

$\mathrm{SO}_{4}^{2-}$

0.03

0.04

0.032

0.030

0.05

$\mathrm{PO}_{4}^{3-}$

0.035

0.005

0.035

0.009

0.009

$\mathrm{Cl}^{-}$

0.03

0.005

0.032

0.005

0.005

$\mathrm{Hg}^{a}$

0.00006

0.0017

$0.00006^{b}$

$0.0012^{c}$

$0.0017^{c}$

a. Probably as $\mathrm{HHgO}_{2}^{-}$.

b. This $60 \mu \mathrm{M} / 1 \mathrm{iter}$ may be due to impure chemicals or to occasional use of small amounts of mercury for special purposes; no mercury is used in standard F-Area processes.

c. Probably entirely from the enriched uranium ${ }^{235} \mathrm{U}-\mathrm{Al}$ process; no mercury was used in the H-Area Purex process. 


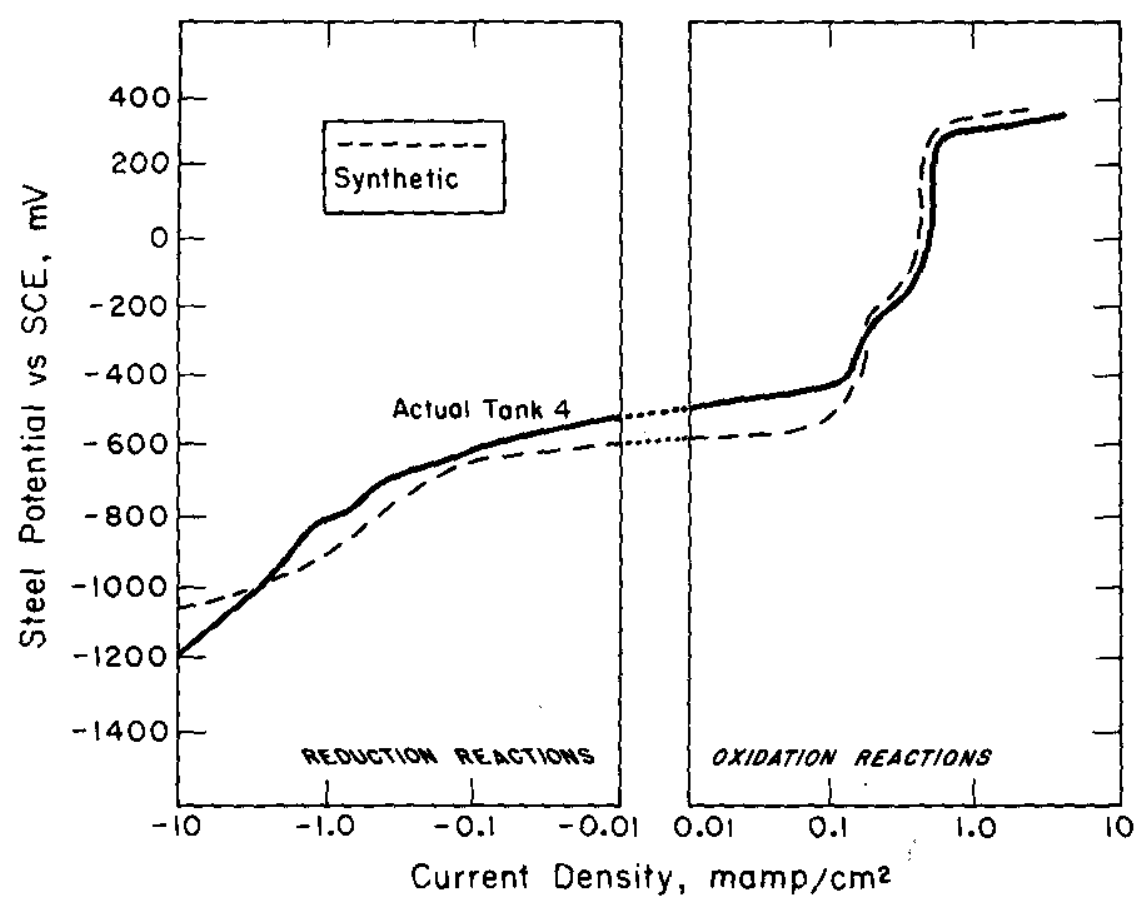

FIG. I POTENTIOSTATIC POLARIZATION OF STEEL IN F-AREA SUPERNATE AT $110^{\circ} \mathrm{C}$

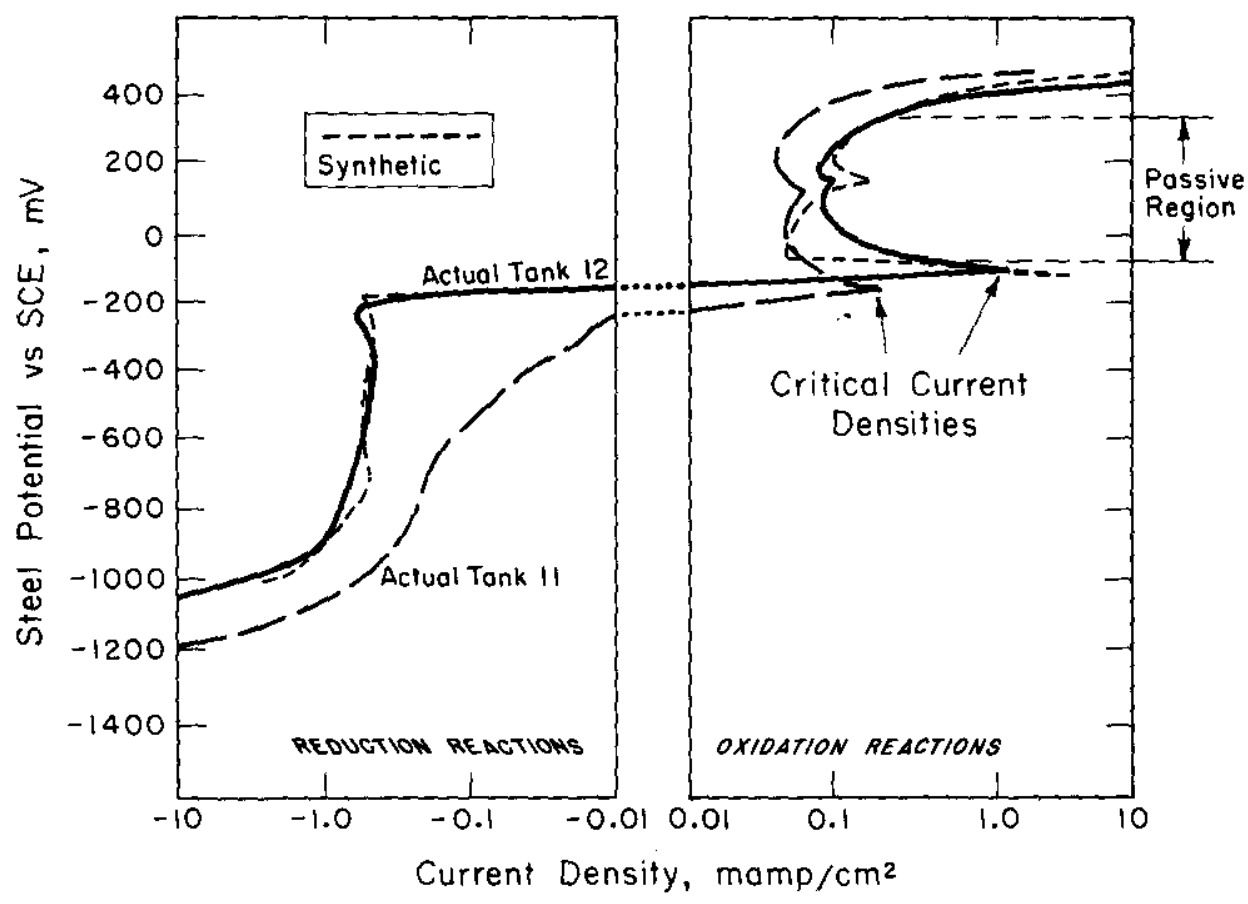

FIG. 2 POTENTIOSTATIC POLARIZATION OF STEEL IN H-AREA SUPERNATE AT $110^{\circ} \mathrm{C}$ 
APPENDIX A. METHODS OF ANALYSIS

\begin{tabular}{|c|c|}
\hline Constituent & Method \\
\hline $\mathrm{NO}_{3}^{-}$ & \multirow{7}{*}{$\begin{array}{l}\text { Laser Raman spectroscopy with } 448 \mathrm{~nm} \text { argon ion } \\
\text { excitation. Nitrate peak was used as an internal } \\
\text { standard after independent nitrate determination } \\
\text { with perchlorate standard. The line frequencies } \\
\text { (wave no./cm) used in the constituent order were } \\
1050,818,625,1080,985,935 \text {, and } 847 \text {, respectively. }\end{array}$} \\
\hline $\mathrm{NO}_{2}^{-}$ & \\
\hline $\mathrm{A} 1(\mathrm{OH}) \overline{4}$ & \\
\hline $\mathrm{CO}_{3}^{-2}$ & \\
\hline $\mathrm{SO}_{4}^{-2}$ & \\
\hline $\mathrm{PO}_{4}^{-3}$ & \\
\hline $\mathrm{CrO}_{4}^{-2}$ & \\
\hline $\mathrm{OH}^{-}$ & $\begin{array}{l}\text { A } \mathrm{pH} \text { electrode method developed for the measurement } \\
\text { of free } \mathrm{H}^{+} \text {and } \mathrm{OH}^{-} \text {in concentrated wastes and certain } \\
\text { other highly salted solutions. }{ }^{15}\end{array}$ \\
\hline $\mathrm{Cl}^{-}$ & Chloride specific ion electrode. \\
\hline $\mathrm{Na}^{+}$ & Atomic absorption using 589 or $330 \mathrm{~nm}$ illumination. \\
\hline $\mathrm{F}^{-}$ & Fluoride specific ion electrode. ${ }^{26}$ \\
\hline $\mathrm{Fe}$ & $\begin{array}{l}\text { Visible light spectrometry of Fe-orthophenanthroline } \\
\text { complex measured at } 510 \mathrm{~nm} \text {. }\end{array}$ \\
\hline $\mathrm{Hg}$ & $\begin{array}{l}\text { a. Measured by flameless atomic absorption of } \\
\text { vapor at } 254 \mathrm{~nm} \text {. Separated from acidic dilution } \\
\text { by amalgamation on Cu wire and vaporized by } \\
\text { resistance heating of wire. }\end{array}$ \\
\hline . & $\begin{array}{l}\text { b. Measured by flameless atomic absorption of } \\
\text { vapor at } 254 \mathrm{~nm} \text {. Vapor produced by air sparging } \\
\text { after solution oxidation with acidic permanganate } \\
\text { and reduction with hydroxylamine and stannous } \\
\text { chloride. }\end{array}$ \\
\hline
\end{tabular}




\section{APPENDIX A (cont'd)}

$\mathrm{NH}_{4}^{+}$

Visible light spectrometry of indophenol complex at $630 \mathrm{~nm}$. Separated by distillation of basic solution into boric acid. ${ }^{17}$

$\mathrm{Ag}$

Determination by spark source mass spectrometry. Separated on Dowex 1-X8 anion resin* after addition of $\mathrm{Ag} 110 \mathrm{~m}$ tracer and formation of chloride complex. Silver eluted with $8 \mathrm{M} \mathrm{HNO}$, and solution fumed with nitric acid to remove chloride ion.

$\mathrm{Pb}$

Measurement of current required for cathodic stripping of anodically deposited $\mathrm{PbO}_{2}$ on a conducting glass electrode from $0.01 \mathrm{H}_{2} \mathrm{SO}_{4}$ solution. ${ }^{18}$

$\mathrm{U}$

Uranium fluorescence of a fused NaF pellet under ultraviolet light excitation after $10 \%$ TBP extraction.

Reducing

Normality

By permanganate titration; SRP method.

Density

Weight of a known volume.

${ }^{243} \mathrm{Am}$

${ }^{141} \mathrm{Ce}$

${ }^{14} \mathrm{Ce}$

${ }^{60} \mathrm{Co}$

$13{ }^{4} \mathrm{Cs}$

${ }^{13{ }^{7} \mathrm{Cs}}$

${ }^{154} \mathrm{Eu}$

${ }^{95} \mathrm{Nb}$

$103 \mathrm{Ru}$

$106 \mathrm{Ru}$

${ }^{9} \mathrm{Zr}$

Measured with a germanium-1ithium-drifted gamma detector connected to a 4096 channel analyzer.

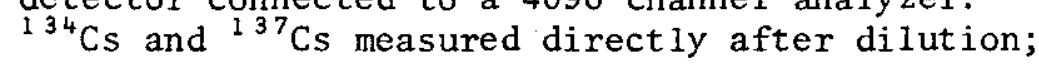
others measured after removal of $\mathrm{Cs}$ isotopes on a Linde AW-500 Zeolite colum pretreated with a synthetic waste solution. ${ }^{19}$

*Product of Dow Chemical Corp., Midland, Michigan. 
APPENDIX A (cont'd)

${ }^{89} \mathrm{Sr}$

Measurement of dilute nitric acid solution by beta

$90 \mathrm{Sr}$ liquid scintillation counting. Separated and purified by $\mathrm{Sr}\left(\mathrm{NO}_{3}\right)_{2}$ precipitation in fuming nitric acid, water dissolution, homogeneous precipitation of $\mathrm{SrSO}_{4}$ with ammonium persulfate, and conversion to $\mathrm{SrCO}_{3}$ by $4 \mathrm{M} \mathrm{K}_{2} \mathrm{CO}_{3}$ wash.

Gross alpha Measurement with a windowless gas-flow-proportional alpha-counter after dilution of solution by a factor of 500 and standard alpha mounting.

Gross beta

Measurement with a Geiger-Muller beta-counter after dilution by a factor of 500 and standard beta-gamma mounting.

Gross gamma Measurement with a thallium-activated sodium iodide scintillation crystal after dilution by a factor of 500 and standard beta-gamma mounting. 


\section{APPENDIX B. TABULAR SUMMARY OF ANALYTICAL DATA}

The tank farms in F- and H-Areas contain 24 large tanks built before 1970 for storing radioactive liquid wastes. F-Area tanks are numbered 1 through 8 and 17 through 20 . H-Area tanks are numbered 9 through 16 and 21 through 24 . Tanks 1 through 16 are double-walled, cooled tanks for storing highly radioactive aqueous wastes. The remaining tanks, 17 through 24, are singlewalled and uncooled and have contained relatively low-level aqueous wastes, e.g., solutions with activities of a factor of 10 or more lower than high level liquid wastes. In the following tables, Tank 3 was omitted as its contents were similar to those of Tanks 4 and 5 . Tank 7 was omitted as waste solutions are pumped through it to Tank 18 . Tank 16 was also omitted from the sampling schedule as it was retired from service in March 1973, and the supernate was transferred to other tanks. The following tables summarize the data obtained by analyzing the sampled supernates of the waste tanks. The six tanks completed since 1970 were not sampled. 
F-AREA WASTE TANK SUPERNATE ANALYSES - I

\begin{tabular}{|c|c|c|c|c|c|c|c|c|c|c|}
\hline \multirow{2}{*}{$\begin{array}{l}\text { Tank } \\
\text { No. }\end{array}$} & \multirow{2}{*}{$\begin{array}{c}\text { Date } \\
\text { Sampled } \\
\end{array}$} & \multicolumn{9}{|c|}{ Concentration, $\mathrm{M}$} \\
\hline & & $\mathrm{Na}^{+}$ & №- & $\mathrm{NO}_{2}^{-}$ & $\mathrm{Al}(\mathrm{OH})_{4}^{-}$ & $\underline{\mathrm{OH}^{-}}$ & $\mathrm{CO}_{3}^{-2}$ & $\mathrm{SO}_{4}^{-2}$ & $\mathrm{PO}_{4}{ }^{\mathrm{a}}$ & $\mathrm{Cl}^{-}$ \\
\hline 1 & $2 / 21 / 73$ & 10.1 & 1.6 & 2.4 & 0.8 & 6.3 & $<0.1$ & 0.02 & 0.08 & 0.06 \\
\hline 2 & $2 / 20 / 73$ & 9.3 & 2.4 & 2.9 & 0.7 & 4.5 & $<0.1$ & 0.02 & 0.04 & 0.06 \\
\hline 4 & $6 / 23 / 72$ & - & 2.4 & 3.1 & 0.5 & 2.8 & 0.2 & 0.03 & 0.04 & 0.03 \\
\hline 5 & $3 / 1 / 73$ & 9.4 & 2.4 & 3.1 & 0.7 & 4.4 & $<0.1$ & 0.02 & 0.04 & 0.06 \\
\hline 6 & $3 / 1 / 73$ & 5.0 & 1.6 & 1.1 & 0.4 & 1.7 & 0.1 & 0.14 & 0.02 & 0.04 \\
\hline 8 & $3 / 8 / 73$ & 4.0 & 1.7 & 0.5 & 0.4 & 1.1 & $<0.1$ & 0.18 & 0.02 & 0.03 \\
\hline 18 & $9 / 7 / 72$ & 12.5 & 2.5 & 2.6 & 0.7 & 3.4 & 0.3 & 0.02 & 0.03 & 0.11 \\
\hline
\end{tabular}

- Not requested

F-AREA WASTE TANK SUPERNATE ANALYSES - II

\begin{tabular}{|c|c|c|c|c|c|c|c|c|c|c|c|}
\hline \multirow{3}{*}{$\begin{array}{l}\text { Tank } \\
\text { No. } \\
\end{array}$} & \multirow{3}{*}{$\begin{array}{c}\text { Date } \\
\text { Sampled }\end{array}$} & \multicolumn{8}{|c|}{ Concentration } & \multirow{3}{*}{$\begin{array}{l}\text { Red. } \\
\text { Norm. }\end{array}$} & \multirow{3}{*}{$\begin{array}{c}\text { Density, } \\
\mathrm{g} / \mathrm{m} 1\end{array}$} \\
\hline & & \multicolumn{2}{|c|}{$M$} & \multirow{2}{*}{$\underline{\underline{\mathrm{M}}}$} & \multicolumn{5}{|c|}{$\mu \mathrm{g} / \mathrm{m} 1$} & & \\
\hline & & $\mathrm{CrO}_{4}-2$ & $\mathrm{~F}^{-}$ & & $\mathrm{Hg}$ & $\mathrm{NH}_{4}^{+}$ & $\mathrm{Ag}$ & $\mathrm{Pb}$ & $\mathrm{U}$ & & \\
\hline 1 & $2 / 21 / 73$ & 0.008 & 0.002 & 500 & 30 & 7 & 3 & $<0.2$. & 5 & 0.005 & 1.41 \\
\hline 2 & $2 / 20 / 73$ & 0.004 & 0.002 & 320 & $<20$ & 13 & 0.04 & $<0.2$ & 5 & 0.28 & 1.41 \\
\hline 4 & $6 / 23 / 72$ & 0.009 & - & - & 12 & - & - & - & 16 & - & - \\
\hline 5 & $3 / 1 / 73$ & 0.007 & 0.002 & 390 & 60 & 11 & 0.1 & $<0.2$ & 4 & 0.02 & 1.40 \\
\hline 6 & $3 / 1 / 73$ & 0.006 & 0.003 & 80 & 320 & 9 & $<0.04$ & $<0.2$ & 4 & 0.01 & 1.22 \\
\hline 8 & $3 / 8 / 73$ & 0.007 & 0.004 & 70 & 40 & 28 & $<0.04$ & $<0.2$ & 13 & 0.01 & 1.20 \\
\hline 18 & $9 / 7 / 72$ & 0.006 & - & - & $<20$ & - & - & - & 10 & - & - \\
\hline
\end{tabular}

- Not requested 


\begin{tabular}{|c|c|c|c|c|c|c|c|c|c|c|}
\hline \multirow{2}{*}{$\begin{array}{l}\text { Tank } \\
\text { No. } \\
\end{array}$} & \multirow{2}{*}{$\begin{array}{c}\text { Date } \\
\text { Sampled } \\
\end{array}$} & \multicolumn{2}{|c|}{$10^{9} \mathrm{~d} /(\min )(\mathrm{m} 1)$} & \multicolumn{2}{|c|}{$10^{6} \mathrm{~d} /(\min )(\mathrm{ml})$} & \multicolumn{5}{|c|}{$10^{3} \mathrm{~d} /(\min )(\mathrm{ml})$} \\
\hline & & ${ }^{134} \mathrm{Cs}$ & ${ }^{137} \mathrm{Cs}$ & $10{ }^{3} \mathrm{Ru}$ & ${ }^{106} \mathrm{Ru}$ & $243 \mathrm{Am}$ & ${ }^{141} \mathrm{Ce}$ & ${ }^{144} \mathrm{Ce}$ & ${ }^{154} \mathrm{Eu}$ & ${ }^{95} \mathrm{Nb}$ \\
\hline 1 & $2 / 21 / 73$ & 0.3 & 14 & ND & 140 & $<50$ & ND & ND & ND & $\mathrm{ND}$ \\
\hline 2 & $2 / 20 / 73$ & 0.1 & 8 & ND & 140 & $<80$ & ND & ND & ND & $\mathrm{ND}$ \\
\hline 4 & $6 / 23 / 72$ & 2.7 & 11 & - & - & - & - & - & - & - \\
\hline 5 & $3 / 1 / 73$ & 0.2 & 23 & $<0.008$ & 25 & 8 & $\mathrm{ND}$ & $<30$ & 10 & 30 \\
\hline 6 & $3 / 1 / 73$ & 0.3 & 4 & $<0.1$ & 200 & 120 & ND & $<300$ & $<100$ & 98 \\
\hline 8 & $3 / 8 / 73$ & 0.5 & 26 & 108 & 670 & $<210$ & ND & $<150$ & $<360$ & $<250$ \\
\hline 18 & $9 / 7 / 72$ & 0.1 & 11 & 0.1 & 30 & $<20$ & $\mathrm{ND}$ & $<80$ & $<80$ & $<24$ \\
\hline
\end{tabular}

- Not requested; also, cobalt-60 activity was not requested for these tank samples.

ND Not detected in gamna scan after cesium removal, see Appendix A.

\section{F-AREA WASTE TANK SUPERNATE ANALYSES - IV}

\begin{tabular}{|c|c|c|c|c|c|c|c|c|c|}
\hline \multirow[b]{3}{*}{$\begin{array}{l}\text { Tank } \\
\text { No. }\end{array}$} & \multirow[b]{3}{*}{$\begin{array}{c}\text { Date } \\
\text { Sampled } \\
\end{array}$} & \multicolumn{8}{|c|}{ Activity } \\
\hline & & \multicolumn{5}{|c|}{$10^{3} \mathrm{~d} /(\min )(\mathrm{mI})$} & & \multicolumn{2}{|c|}{$10^{6} \mathrm{c} /(\mathrm{min})(\mathrm{m} 1)$} \\
\hline & & ${ }^{89} \mathrm{Sr}$ & ${ }^{90} \mathrm{Sr}$ & ${ }^{95} \mathrm{Zr}$ & Gross $\alpha$ & Total Pu & $\therefore$ & $\begin{array}{l}\text { Gross } \\
\text { Beta } \\
\end{array}$ & $\begin{array}{l}\text { Gross } \\
\text { Gamma } \\
\end{array}$ \\
\hline 1 & $2 / 21 / 73$ & $<5$ & 500 & ND & $<0.5$ & 0.4 & & 60 & 200 \\
\hline 2 & $2 / 20 / 73$ & $<2$ & 100 & ND & $<0.5$ & $<0.1$ & & 30 & 240 \\
\hline 4 & $6 / 23 / 72$ & - & - & - & - & 5 & & - & - \\
\hline 5 & $3 / 1 / 73$ & $<9$ & 900 & $<10$ & 10 & 0.2 & & 70 & 150 \\
\hline 6 & $3 / 1 / 73$ & $<7$ & 700 & $<120$ & 10 & 0.3 & & 70 & 80 \\
\hline 8 & $3 / 8 / 73$ & $<10$ & 1200 & $<360$ & 9 & 0.2 & & 60 & 120 \\
\hline 18 & $9 / 7 / 72$ & - & - & 50 & - & 4 & & - & - \\
\hline
\end{tabular}

\footnotetext{
- Not requested.
}

ND Not detected in gamma scan after cesium removal. 
H-AREA WASTE TANK SUPERNATE ANALYSES - I

\begin{tabular}{|c|c|c|c|c|c|c|c|c|c|c|}
\hline \multirow{2}{*}{$\begin{array}{l}\text { Tank } \\
\text { No. } \\
\end{array}$} & \multirow{2}{*}{$\begin{array}{c}\text { Date } \\
\text { Sampled }\end{array}$} & \multicolumn{9}{|c|}{ Concentration, $\mathrm{M}$} \\
\hline & & $\mathrm{Na}^{+}$ & $\underline{\mathrm{NO}_{3}^{-}}$ & $\underline{\mathrm{NO}_{2}^{-}}$ & $\mathrm{Al}(\mathrm{OH})_{\overline{4}}^{-}$ & $\underline{\mathrm{OH}^{-}}$ & $\mathrm{CO}_{3}^{-2}$ & $\mathrm{SO}_{4}^{-2}$ & $\mathrm{PO}_{4}^{-3}$ & $\mathrm{Cl}^{-}$ \\
\hline 9 & $1 / 11 / 73$ & 12.5 & 1.9 & 3.2 & 1.6 & 3.8 & 0.1 & 0.02 & 0.05 & 0.029 \\
\hline 10 & $1 / 5 / 73$ & 9.1 & 4.5 & 1.8 & 1.0 & 1.9 & $<0.1$ & 0.08 & 0.02 & 0.020 \\
\hline 11 & $7 / 11 / 72$ & - & 3.7 & 0.6 & 0.9 & 0.8 & 0.1 & 0.03 & 0.009 & 0.005 \\
\hline 12 & $7 / 11 / 72$ & - & 3.3 & 1.1 & 0.7 & 1.0 & 0.2 & 0.03 & 0.009 & 0.005 \\
\hline 13 & $12 / 19 / 72$ & 5.7 & 3.6 & 0.5 & 0.4 & 1.1 & 0.1 & 0.08 & 0.02 & 0.018 \\
\hline 14 & $1 / 3 / 72$ & 8.9 & 2.8 & 2.0 & 1.1 & 2.5 & $<0.1$ & 0.04 & 0.01 & 0.019 \\
\hline 15 & $12 / 19 / 72$ & 6.2 & 3.6 & 1.1 & 1.0 & 1.0 & 0.1 & 0.05 & $<0.01$ & 0.016 \\
\hline 21 & $5 / 4 / 72$ & - & 6.4 & 0.2 & 1.2 & 2.6 & 0.3 & 0.06 & 0.009 & 0.015 \\
\hline 21 & $6 / 19 / 72$ & - & 5.3 & 1.5 & 1.0 & 2.6 & 0.1 & 0.05 & 0.009 & 0.020 \\
\hline 24 & $2 / 6 / 73$ & 9.4 & 2.6 & 1.7 & 0.9 & 4.3 & $<0.1$ & 0.02 & $<0.02$ & 0.040 \\
\hline
\end{tabular}

Not requested.

H-AREA WASTE TANK SUPERNATE ANALYSES - II

Concentration

\begin{tabular}{|c|c|c|c|c|c|c|c|c|c|c|c|}
\hline \multirow{3}{*}{$\begin{array}{l}\text { Tank } \\
\text { No. } \\
\end{array}$} & \multirow{3}{*}{$\begin{array}{c}\text { Date } \\
\text { Sampled } \\
\end{array}$} & \multicolumn{8}{|c|}{ Concentration } & \multirow{3}{*}{$\begin{array}{l}\text { Red. } \\
\text { Norm. }\end{array}$} & \multirow{3}{*}{$\begin{array}{c}\text { Density, } \\
\mathrm{g} / \mathrm{m} 1\end{array}$} \\
\hline & & \multicolumn{2}{|c|}{$M$} & \multirow{2}{*}{$\frac{\mu \mathrm{M}}{\mathrm{Fe}}$} & \multicolumn{5}{|c|}{$\mu \mathrm{g} / \mathrm{ml}$} & & \\
\hline & & $\mathrm{CrO}_{4}^{-2}$ & $\mathrm{~F}^{-}$ & & $\mathrm{Hg}$ & $\underline{\mathrm{NH}_{4}^{+}}$ & $\mathrm{Ag}$ & $\mathrm{Pb}$ & $\mathrm{U}$ & & \\
\hline 9 & $1 / 11 / 73$ & 0.003 & 0.002 & 0.2 & 130 & 6 & 0.3 & 5 & 3 & 0.3 & 1.41 \\
\hline 10 & $1 / 5 / 73$ & 0.002 & 0.003 & 0.2 & 280 & $<1$ & 0.2 & 2 & 2 & $<0.01$ & 1.39 \\
\hline 11 & $7 / 11 / 72$ & 0.005 & - & - & 240 & - & - & - & 0.5 & - & - \\
\hline 12 & $7 / 11 / 72$ & 0.002 & - & - & 340 & - & - & - & 0.4 & - & - \\
\hline 13 & $12 / 19 / 72$ & 0.001 & $0.00 \overline{1}$ & 6 & 120 & 67 & 0.3 & 10 & 1 & $<0.01$ & 1.20 \\
\hline 14 & $1 / 3 / 73$ & 0.003 & 0.004 & 0.3 & 110 & 2 & 4 & 58 & 3 & $<0.01$ & 1.38 \\
\hline 15 & $12 / 19 / 72$ & 0.002 & 0.001 & 0.2 & 100 & $<1$ & 0.1 & 6 & 2 & 0.02 & 1.29 \\
\hline 21 & $5 / 4 / 72$ & 0.002 & - & - & 60 & - & - & - & 3 & - & - \\
\hline 21 & $6 / 19 / 72$ & 0.002 & - & - & 60 & - & - & - & 6 & - & - \\
\hline 24 & $2 / 6 / 73$ & 0.001 & 0.003 & 46 & 120 & 31 & 0.4 & 14 & 2 & 0.01 & 1.39 \\
\hline
\end{tabular}

Not requested. 
H-AREA WASTE TANK SUPERNATE ANALYSES - III

\begin{tabular}{|c|c|c|c|c|c|c|c|c|c|c|c|}
\hline \multirow{3}{*}{$\begin{array}{l}\text { Tank } \\
\text { No. } \\
\end{array}$} & \multirow{3}{*}{$\begin{array}{c}\text { Date } \\
\text { Sampled } \\
\end{array}$} & \multicolumn{10}{|c|}{ Activity } \\
\hline & & \multicolumn{2}{|c|}{$10^{9} \mathrm{~d} /(\min )(\mathrm{ml})$} & \multicolumn{2}{|c|}{$10^{6} \mathrm{~d} /(\min )(\mathrm{ml})$} & \multicolumn{6}{|c|}{$10^{3} \mathrm{~d} /(\min )(\mathrm{m} 1)$} \\
\hline & & ${ }^{234} \mathrm{Cs}$ & ${ }^{137} \mathrm{Cs}$ & ${ }^{103} \mathrm{Ru}$ & ${ }^{106} \mathrm{Ru}$ & $2{ }^{4{ }^{3} \mathrm{Am}}$ & ${ }^{142} \mathrm{Ce}$ & ${ }^{144} \mathrm{Ce}$ & ${ }^{60} \mathrm{Co}$ & ${ }^{254} \mathrm{Eu}$ & $95_{\mathrm{Nb}}$ \\
\hline 9 & $1 / 11 / 73$ & 0.09 & 4 & $<0.004$ & 4 & 3 & $<26$ & $<260$ & 4 & 3 & $<2$ \\
\hline 10 & $1 / 5 / 73$ & 0.6 & 8 & $<0.03$ & 4 & $<2$ & $<2$ & $<20$ & 7 & $<4$ & $<2$ \\
\hline 11 & $7 / 11 / 72$ & - & - & - & - & - & - & - & - & - & - \\
\hline 12 & $7 / 11 / 72$ & - & - & - & - & - & - & - & - & - & - \\
\hline 13 & $12 / 19 / 72$ & 0.2 & 1 & 2.9 & 3 & $<3$ & $<1$ & $<10$ & $<2$ & $<2$ & 1 \\
\hline 14 & $1 / 3 / 73$ & 0.2 & 2 & $<0.001$ & 0.9 & 2 & $<1$ & $<5$ & 3 & 2 & $<0.9$ \\
\hline 15 & $12 / 19 / 72$ & 1 & 5 & 0,009 & 2 & $<1$ & $<1$ & $<10$ & 4 & $<2$ & $<1$ \\
\hline 21 & $5 / 4 / 72$ & - & - & - & - & - & - & - & - & - & - \\
\hline 21 & $6 / 19 / 72$ & - & - & - & - & - & - & - & - & - & - \\
\hline 24 & $2 / 6 / 73$ & - & - & - & - & - & - & - & - & - & - \\
\hline
\end{tabular}

H-AREA WASTE SUPERNATE ANALYSES - IV

\begin{tabular}{|c|c|c|c|c|c|c|c|c|}
\hline \multirow[b]{3}{*}{$\begin{array}{l}\text { Tank } \\
\text { No. }\end{array}$} & \multirow[b]{3}{*}{$\begin{array}{c}\text { Date } \\
\text { Sampled }\end{array}$} & \multicolumn{7}{|c|}{ Activity } \\
\hline & & \multicolumn{5}{|c|}{$10^{3} \mathrm{~d}^{\prime}(\min )(\mathrm{ml})$} & \multicolumn{2}{|c|}{$10^{6} \mathrm{c} /(\min )(\mathrm{m} 1)$} \\
\hline & & ${ }^{89} \mathrm{Sr}$ & ${ }^{90} \mathrm{Sr}$ & ${ }^{95} \mathrm{Zr}$ & Gross $\alpha$ & Total Pu & $\begin{array}{l}\text { Gross } \\
\text { Beta } \\
\end{array}$ & $\begin{array}{l}\text { Gross } \\
\text { Gamma }\end{array}$ \\
\hline 9 & $1 / 11 / 73$ & $<3$ & 300 & $<6$ & 400 & 30 & 20 & 80 \\
\hline 10 & $1 / 5 / 73$ & $<0.4$ & 40 & $<6$ & 250 & 140 & 30 & 30 \\
\hline 11 & $7 / 11 / 72$ & - & - & - & - & 2 & - & - \\
\hline 12 & $7 / 11 / 72$ & - & - & - & - & 0.01 & - & - \\
\hline 13 & $12 / 19 / 72$ & $<0.2$ & 20 & $<3$ & 30 & 8 & 20 & 20 \\
\hline 14 & $1 / 3 / 73$ & $<20$ & 1800 & $<3$ & 80 & 60 & 30 & 60 \\
\hline 15 & $12 / 19 / 72$ & $<20$ & 2100 & $<3$ & 5 & 2 & 40 & 50 \\
\hline 21 & $5 / 4 / 72$ & - & - & - & - & 5 & - & - \\
\hline 21 & $6 / 19 / 72$ & - & - & - & - & 5 & - & - \\
\hline 24 & $2 / 6 / 72$ & $<20$ & 2300 & - & 10 & - & 40 & 40 \\
\hline
\end{tabular}

Not requested. 


\section{REFERENCES}

1. L. P. Coastas, M. L. Holzworth, and W. C. Rion. Stress Corrosion Cracking of Carbon Steel in Simulated Waste Solutions. USAEC REPORT DP-1023, E. I. du Pont de Nemours and Co., Savannah River Laboratory, Aiken, S. C. (1966).

2. R. M. Girdler. Leaks in Radioactive Waste Tanks. USAEC Report DP-990, E. I. du Pont de Nemours and Co., Savannah River Laboratory, Aiken, S. C. (1965).

3. R. M. Wallace, H. L. Hull, and R. F. Bradley. Solid Forms for SRP High Level Waste. USAEC Report DP-1335, E. I. du Pont de Nemours and Co., Savannah River Laboratory, Aiken, S. C. (1974)

4. M. L. Holzworth, R. M. Girdler, and L. P. Costas. "How to Prevent Stress Corrosion Cracking of Radioactive Waste Storage Tanks." Material Protection ? (1), 26-38 (Jan. 1968).

5. H. J. Engell and A. Baumel. "Physical Metallurgy of Stress Corrosion Fracture." Symposium on Physical Metallurgy of Stress Corrosion Fracture - Pittsburgh (1959). T. H. Rhodin, ed., Interscience Publishers, New York, p. 341 (1959).

6. H. L. Logan. The Stress Corrosion of Metals. John Wiley and Sons, Inc. New York, N. Y. (1966).

7. Z. Szklarska-Smialowska. "Effect of Potential of Mild Steel on Stress-Corrosion Cracking in Ammonium Nitrate Solutions." Corrosion 20, 198t (1964).

8. W. Radeker and H. Grafen. "Beobachtungen zum Ablauf de Interkristallinen Spannungrisskorrosion weicher unlegierter Stah1e." Stahi Und Eisen 76, 1616 (1956).

9. M. Smialowski. First Intemational Congress on Metallic Corrosion - 1961. Butterworths. London, p. 296 (1962)

10. R. N. Parkins and R. Usher. First Intermational Congress on Metaliic Corrosion - 1961. Butterworths, London, p. 289 (1962).

11. M. Smialowski and T. Ostrowska. "Mechanism of Intercrystalline Corrosion of Mild Steel by Ammonium Nitrate." Corr. et Anticorn. 5, 76-81 (1957). 
12. E. Herzog. "Intercrystalline Corrosion of Low-Alloy Steels in Nitrate Solutions." Metaux et Corrosion 24, 29 (1949).

13. C. D. Weir. "The Statistics of Boiler Embrittlement." Amer. Soc. Mech. Eng. 70, 253 (1948).

14. R. N. Parkins. "Stress Corrosion Cracking of Low Carbon Steels." Proceedings of Conference - Fundamental Aspects of Stress Corrosion Cracking - September 11-15, 1967. R. W. Staehle, A. J. Forty, and D. Van Rooyan (editors). National Assn. of Corr. Eng., Houston, TX., p. 361-373 (1969).

15. E. W. Baumann. "Determination of $\mathrm{pH}$ in Concentrated Salt Solutions." Anal. Chim. Acta 64, 284-8 (1973).

16. E. W. Baumann. "Trace F1uoride Determination with Specific Ion Electrode." Anal. Chim. Acta 42, 127-32 (1968).

17. "Standard Methods for Examination of Water and Waste Water," 11 th ed. APHA, AWWA, and WPCF, New York, N. Y. (1960). JAWWA 55, No. 5, 657-8 (1963).

18. J. T. Kinard and R. C. Propst. "Determination of Lead at the Parts Per Billion Level by Cathodic Stripping Analysis." Anal. Chem. (to be published).

19. R. V. Slates. Ge/Li-2 SPAN-2 FORTRAN Program to Calculate Nuclide Abundances from Multichannel Gamma Ray Spectra. USAEC Report DP-1275, E. I. du Pont de Nemours and Company, Savannah River Laboratory, Aiken, S. C. (1971). 